\title{
"Own Goodness and Service for Others" A Motivation to Serve People with Mental Disorders: Systematic Review
}

\author{
${ }^{1}$ Flavianus Riantiarno, ${ }^{2}$ Lilik Zuhriyah, ${ }^{3}$ Heni Dwi Windarwati \\ ${ }^{1}$ Master Program of Nursing, Faculty of Medicine, Brawijaya University, Malang, Indonesia \\ ${ }^{2}$ Departemen of Public Health, Faculty of Medicine, Brawijaya University, Malang, Indonesia \\ ${ }^{3}$ Departemen of Nursing, Faculty of Medicine, Brawijaya University, Malang, Indonesia \\ Email: hewinda80@gmail.com
}

\begin{abstract}
Volunteers have an important role in mental health services. Volunteers are present among the stigma and discrimination against people with mental disorders. To understand the motivation of volunteers in caring for people with mental disorders. A systematic review was conducted by collecting the results of scientific publications. The data bases used were ProQuest, PubMed, Sincedirect, and Springer link. Searching was carried out using the keywords of motivation, volunteers and mental disorders. Determination of the number of articles and articles contained in the review was determined by using PRISMA methods. Eight articles were found using the inclusion criteria for the article. Volunteer's motivation was for their own goodness and service for others. Motivation of own goodness was divided into personal growth, altruism and selfexistence. Motivation to serve others was to help others and contribute to society. There was strong evidence that volunteers had good motivation in improving the health status of people with mental disorders.
\end{abstract}

Keywords: Motivation, Volunteer, Mental Disorder.

\section{A. INTRODUCTION}

Mental health is one of the issues that become a concern of world. The increasing prevalence of people with mental disorder shows that this is a serious problem. World Health Organization (2018) estimates that mental health problems will become the second number problem in the world by 2030. The prevalence of people with mental disorder is increasing. One in four people in the world experience a mental disorder (WHO, 2018). This shows that, indeed, the problem of mental disorder is a very serious problem and an effort is needed to prevent or overcome it.

Many factors that cause the increment of people with mental disorder. One factor is the system and efforts of health services that are not good and not integrated (Ayalon, 2008). It is also influenced by the community stigma and discrimination towards people with mental disorders (AlAteeq et al., 2018). These factors cause a lack of attention to mental disorders. As a result, the problem of people with mental disorders continues to increase. Although, everyone should have the right to get health services.

One obstacle in creating good mental health service is the level of public knowledge about mental health. The community stigma and discrimination against 
people with mental health problems are still present (Li et al., 2019). The community considers that people with mental disorders is a common problem and only can be overcome by conducting retirement or exile. People with mental disorder can often face negative stereotypes and community discrimination (Hallet et al., 2012). Society also has a tendency to distance themselves from people with mental disorder. Even though, as known that the community is not all like that. There are still people who have a positive attitude towards people with mental disorders.

However, there are still many communities that still have a good concern for people with mental disorders. There are still people who have good knowledge and thoughts towards people with mental disorders (Naylor et al., 2013). The community seeks direct contact and offers their free time to support individuals with mental disorder (Toner et al., 2018). This conscious community is a community that cares about mental health or cares about people with mental disorders. People who volunteer their time to meet, care for and help people with mental disorders. This group of volunteers has been formed and has provided mental health services.

Volunteers are some people who carry out services without paid (Hallet et al., 2012; Naylor et al., 2013). As in health services in general, volunteers also have an important role in mental health services (Naylor et al., 2013; Toner et al., 2018), especially in treating people with mental disorders. Voluntary services provided to those around them. Volunteers will deal with people who have mental disorder, are vulnerable to violent behavior and can be dangerous. Volunteers will also be faced with community stigma and discrimination against people with mental disorders.

The systematic review will review the motivation of volunteers in serving people with mental disorder. Many of the literature that unfolds relates to volunteer motivation and the benefits that people with mental disorders obtained. Tonner et al (2018), discussed related to motivation and focused on one program that is making friends. Hallet et al (2012) discussed generally related to volunteers in the service of people with mental health problems. Both of these literatures still use literature (research) which is a little longer to be the material for their review. However, both of these literature are references that enrich this review.

\section{B. METHOD}

\section{Literature Search Strategy}

This systematic review is carried out by collecting the results of scientific publications by searching in Google Search by searching in the databases of ProQuest, PubMed, Sincedirect and Springer Link. Searching by using keywords of Motivation, Volunteers and mental disorder. Guidelines used in determining the number of articles and articles published in a review was determined by using PRISMA method. 


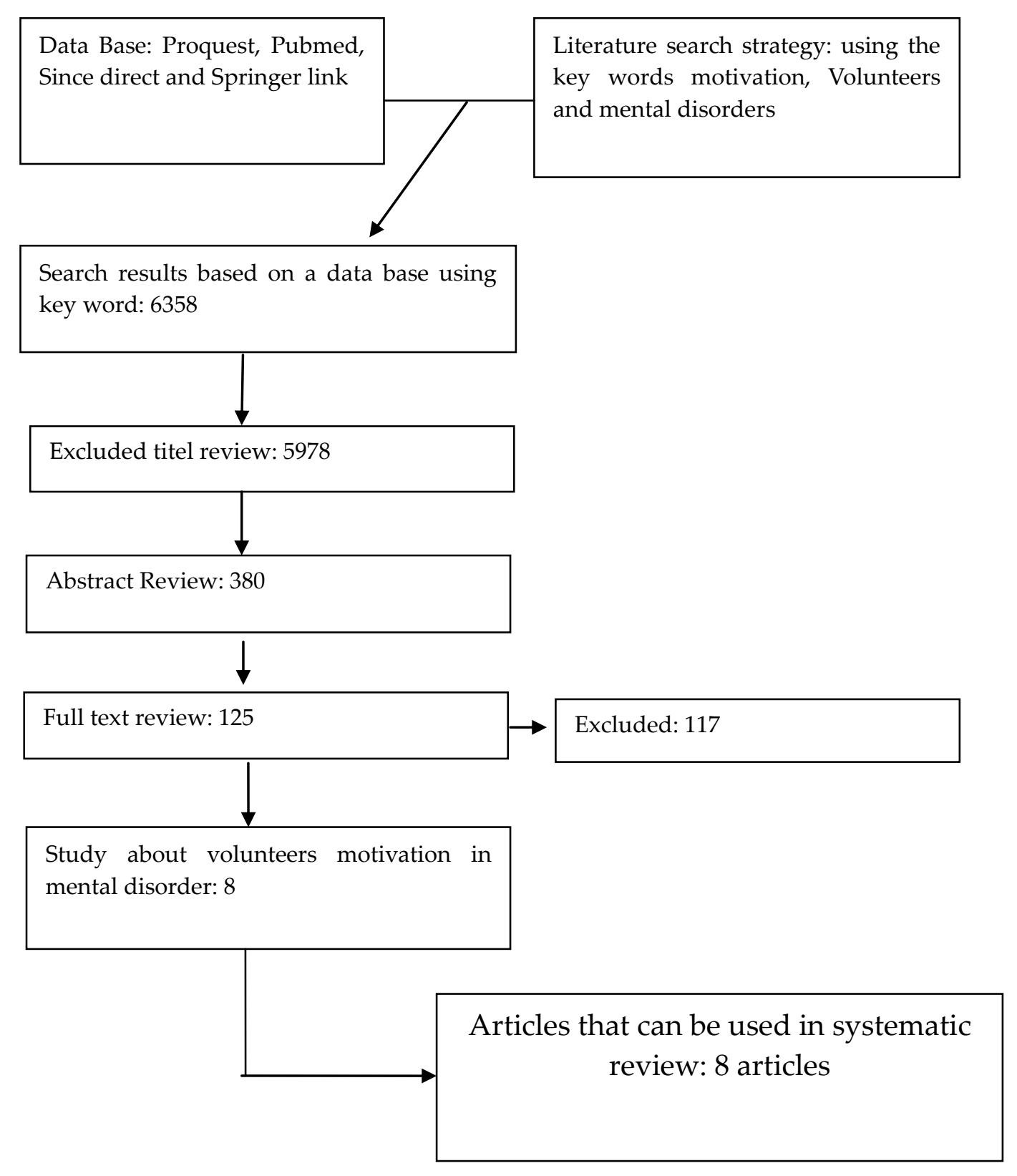

Figure 1 Process and Outcome of the Literature Search

\section{Inclusion Criteria}

Titles and abstracts are examined to identify relevant reviews. Articles will be included if they meet the inclusion criteria. Articles with qualitative and quantitative research methods from 2000-2019, volunteers are professionals or non-professionals, volunteers are directly involved with people who have mental health problems and volunteers who provide services or care for people with mental disorders. The final text identified will be examined independently by the author to determine the article match. 


\section{Data Extraction}

Qualitative and quantitative data were extracted by the authors. Extraction instruments included studies (author, title, year, country, objective and method), Characteristics of Volunteers (number, age, gender, work status, relationship status, previous mental health history and motivation to be volunteer), people with mental health problems (All types of mental disorders, mental health services by volunteers. The results of the study conducted by the author then made a category which then determined the themes.

Table 1

Summary of Papers Included in the Systematic Review

\begin{tabular}{|c|c|c|c|c|c|c|c|c|}
\hline Author & Country & Year & $\begin{array}{l}\text { Study } \\
\text { Design }\end{array}$ & $\begin{array}{l}\text { Number of } \\
\text { Volunteer } \\
\text { interview }\end{array}$ & $\begin{array}{l}\text { Volunteer } \\
\text { age }\end{array}$ & $\begin{array}{l}\text { Volunteer } \\
\text { gender }\end{array}$ & $\begin{array}{c}\text { Type } \\
\text { patient of } \\
\text { mental } \\
\text { health } \\
\text { problems }\end{array}$ & $\begin{array}{c}\text { Type of } \\
\text { Volunteer }\end{array}$ \\
\hline Cassidy, et al & USA & 2009 & $\begin{array}{l}\text { Qualitative } \\
\text { Interview, } \\
\text { semi- } \\
\text { structured } \\
\text { interview, }\end{array}$ & 20 & Not detail & Not detail & $\begin{array}{l}\text { People in } \\
\text { treatment } \\
\text { for SMI } \\
\text { (called } \\
\text { 'clients'). }\end{array}$ & $\begin{array}{l}\text { Compeer } \\
\text { Friends }\end{array}$ \\
\hline $\begin{array}{l}\text { Fegan, } C \mathcal{E} \\
\text { Cook, } S\end{array}$ & UK & 2012 & $\begin{array}{l}\text { Qualitative } \\
\text { Interview, } \\
\text { Indepth } \\
\text { Interview }\end{array}$ & 11 & $18-24$ & M:4, F:7 & $\begin{array}{l}\text { People wit } \\
\text { mental } \\
\text { ilnes }\end{array}$ & $\begin{array}{l}\text { people with } \\
\text { serious } \\
\text { mental ill- } \\
\text { ness per- } \\
\text { ceived the } \\
\text { experience } \\
\text { of volun- } \\
\text { teering } \\
\text { for the } \\
\text { health care } \\
\text { organization }\end{array}$ \\
\hline Jensen, et al & Denmark & 2016 & $\begin{array}{l}\text { Qualitative } \\
\text { Interview, } \\
\text { Focus group } \\
\text { interviews }\end{array}$ & 16 & Not detail & Not detail & $\begin{array}{l}\text { people } \\
\text { with severe } \\
\text { mental } \\
\text { illness }\end{array}$ & $\begin{array}{l}\text { Volunter } \\
\text { Family }\end{array}$ \\
\hline $\begin{array}{l}\text { Ørtenblad, } \\
\text { et al }\end{array}$ & Denmark & 2017 & $\begin{array}{l}\text { Qualitative } \\
\text { Interview, } \\
\text { Focus group } \\
\text { interviews }\end{array}$ & 17 & $20-69$ & M:5, F:12 & $\begin{array}{l}\text { people } \\
\text { with severe } \\
\text { mental } \\
\text { illness }\end{array}$ & $\begin{array}{l}\text { Volunter in } \\
\text { Community } \\
\text { Family Pro- } \\
\text { gramme }\end{array}$ \\
\hline $\begin{array}{l}\text { Sundram, et } \\
\text { al }\end{array}$ & New Zealand & 2018 & $\begin{array}{l}\text { Fokus group } \\
\text { and individ- } \\
\text { ual inter- } \\
\text { view }\end{array}$ & 25 & $25-67$ & M:2, F: 23 & $\begin{array}{l}\text { General } \\
\text { mental } \\
\text { health } \\
\text { context }\end{array}$ & $\begin{array}{l}\text { Mental } \\
\text { Health } \\
\text { Helplines } \\
\text { Volunteer }\end{array}$ \\
\hline Klug, et al & Austria & 2018 & $\begin{array}{l}\text { Survey of } \\
\text { volunteers }\end{array}$ & 360 & $\begin{array}{c}\text { Mean age: } \\
54,5\end{array}$ & $\begin{array}{l}\text { M:75, } \\
F: 285\end{array}$ & $\begin{array}{l}\text { Pepole } \\
\text { with men- } \\
\text { tal ilnnes }\end{array}$ & Briefnding \\
\hline $\begin{array}{l}\text { Perez- } \\
\text { Corrales, et } \\
\text { al }\end{array}$ & Spain & 2019 & $\begin{array}{l}\text { Qualitative } \\
\text { Interview, } \\
\text { in-depth } \\
\text { interviews }\end{array}$ & 23 & $\begin{array}{l}\text { 18-65, } \\
\text { mean age } \\
\quad: 47\end{array}$ & $\mathrm{M}: 16, \mathrm{~F}: 7$ & $\begin{array}{l}\text { with a } \\
\text { diagnosis } \\
\text { of a non- } \\
\text { organic } \\
\text { psychotic }\end{array}$ & $\begin{array}{l}\text { support for } \\
\text { people with } \\
\text { severe } \\
\text { mental dis- } \\
\text { order in }\end{array}$ \\
\hline
\end{tabular}




\begin{tabular}{|l|l|l|l|l|l|l|l|l|}
\hline & & & & & & disorder & $\begin{array}{l}\text { different } \\
\text { activities }\end{array}$ \\
\hline $\begin{array}{l}\text { Mccorkle, et } \\
\text { al }\end{array}$ & UK & 2019 & $\begin{array}{l}\text { Qualitative } \\
\text { Interview, } \\
\text { Semi- } \\
\text { structured } \\
\text { interview }\end{array}$ & 38 & $\begin{array}{l}20-68 \\
\text { years, } \\
\text { mean age: } \\
42,4\end{array}$ & M:9, F:29 & $\begin{array}{l}\text { People wit } \\
\text { mental } \\
\text { ilnes }\end{array}$ & Briefnding \\
& & & & & \\
\hline
\end{tabular}

\section{RESUlt AND Discussion}

\section{Total articles}

The searching found a total of 6358 papers which were then filtered. Filter results based on the title and inclusion criteria found 28 articles. The articles are then filtered by looking at duplicate articles, irrelevant articles and abstract titles and articles that fit to the inclusion criteria. The final result, as many as eight studies that reported related to volunteer motivation. The search results and selection of literature are detailed in Figure 1.

The articles reviewed are the results of research published from 2000-2019. The author of the article consists of several countries. One from the USA, two from Denmark, two from the UK, one from Austria, one from Spain and one from New Zealand. Almost all data collection techniques are interviews (in direct or in-depth interviews), two of which use questionnaires. All articles are in English. Articles that have more than 100 participants (volunteers) is only one, while others have fewer than 100 participants. The total number of volunteers was 510, out of eight articles.

\section{Characteristics of Volunteers}

The study shows, the number of volunteers in this article is 510 people. Volunteers are between 18- 69 years old. Genders vary between men and women, but dominated by women, work varies, there are those who are working, there are health workers or professionals and non-professionals, unemployment and retires. There are volunteers who are family or not family of people with mental disorders. There are also volunteers who are former people with mental disorders or have experienced mental health problems.

\section{Activity of Volunteers}

Volunteers serve or treat people with mental health problems with various activities. Volunteers carry out the activities of being friends, assisting in care, providing assistance and health education. Volunteers often say that they don't do anything special, other than just being with someone else as a friend. Volunteers describe the relationship as friendship. Volunteers do it by making friends, telling stories, doing assistance, socializing with the community and recreation. 


\section{Motivation}

Several articles show the motivation of volunteers in providing services to people with mental health problems. There are two main themes of motivation from volunteers. First is their own goodness. The second is to serve others. According to the two themes, further divided into several sub-themes (can be seen in table 2)

\section{Own Goodness}

Volunteers have motivation for self-development, increase self-awareness about mental health issues and gain new skills, especially in caring for or serving people with mental disorders (Cassidy et al., 2019; Corrales-Perez et al., 2019; Farrell \& Bryant, 2009; hallet et al., 2012; Mccorkle et al., 2009). Volunteers have motivation to develop themselves, develop careers, gain new experiences, feel valued, volunteering is a pleasure and an interest and wants to make amends in the past (Cassidy et al., 2019). Volunteers have the motivation to gain the skills and work experience needed for future work, as well as gain skills in psychology (Sundram et al., 2018). Volunteers have the motivation to do new things, find something new in themselves and use their experiences (Fegan \& Cook, 2012). Volunteers want to increase awareness about mental health problems and gain new skills, as well as the experience they have ever had made them aware of the challenges faced by people with mental health problems in building social relationships outside (Ortenblad et al., 2018).

\section{Serve for Others}

Volunteers have the motivation to help others and contribute to the community. Volunteers also have the motivation to help others to do something good for others and feel the responsibility to help others (Jensen et al., 2016; Mccorkle et al., 2009; Ørtenblad et al., 2019). Volunteers have the motivation to be friends or people who are ready to listen, help people with mental disorders who need help (Mccorkle et al., 2009). Volunteers want to contribute to society and make their experiences (have experienced mental problems) to help people with other mental disorders, and expand relationships with others and engage in meaningful relationships (Cassidy et al., 2019; Fegan \& Cook, 2012; Jensen et al., 2016). This means that volunteers have the motivation to help others. There is volunteer awareness that they are social creatures, so volunteers are motivated to help those around them.

Table 2

Themes of Synthesizing Results of Reviewed Studies Related to Motivation

\begin{tabular}{|l|l|l|ll|}
\hline No & Theme & \multicolumn{1}{|c|}{ Sub-themes } & \multicolumn{1}{c|}{ Topics } \\
\hline 1 & Own Goodness & 1. Personal growth & a. & Career development \\
& & & b. Making amends \\
& & & c. $\quad$ New experience and new skills1 8 \\
\hline
\end{tabular}




\begin{tabular}{|c|c|c|c|}
\hline & & $\begin{array}{l}\text { 2. Altruism } \\
\text { 3.Self-existence }\end{array}$ & $\begin{array}{l}\text { d. Fun and interest } \\
\text { e. } \\
\text { f. } \\
\text { g. } \text { Examining the old and new skills } \\
\text { h. Working direction at work } \\
\text { i. Increasing awareness about mental } \\
\text { j. health } \\
\text { k. Religious belief } \\
\text { l. }\end{array}$ \\
\hline 2 & Serve for others & $\begin{array}{l}\text { 1. Help others } \\
\text { 2. Contribute to the com- } \\
\text { munity }\end{array}$ & $\begin{array}{l}\text { a. Doing lots of things for other people } \\
\text { b. Giving care } \\
\text { c. Helping others in need } \\
\text { a. Developing social networks } \\
\text { b. Changing the views of others } \\
\text { c. Feeling the responsibility for others } \\
\text { d. Establishing relationships with others } \\
\text { e. Making a closeness to others } \\
\text { f. Establishing relationships with others } \\
\text { g. Giving something to the community } \\
\text { h. Doing something for the community } \\
\text { i. Meeting new people }\end{array}$ \\
\hline
\end{tabular}

\section{Strengths and Limitations}

This review used a systematic approach to collect all the literature published recently in the volunteers population of mental health. It brought together different literatures, different papers from several countries. There were similarities throughout the country between mental health volunteers in terms of socio-demography, motivation and experience.

The limitation of this article was that it did not discuss in detail what volunteers did. The article did not discuss the programs carried out by volunteers specifically. It 
was interesting if the program and motivation were discussed in detail. Another limitation was that the articles reviewed mostly come from western countries, the similar articles from several countries such as from Asia and Africacouldn't be found, so itwas less varied in social demographics.

\section{Discussion}

This review consisted of 8 papers. Data taken from 520 volunteers reported from the eight papers. The authors of this paper were mostly from western or non-Asian countries so there were demographic characteristics that were not discussed, for example, about ethnicity or culture. However, other demographic data were exposed in the paper. The results showed that volunteers consisted of age, occupation and gender. The age of volunteers ranges from 12-80 years, gender was dominated bywomen. The types of work varied, some people worked and some were unemployed. In addition there were professional and non-professional workforce. The majority of volunteers did not work full time, only using free time. The characteristics of volunteers that needed to be seen were also the medical history of volunteers. There were volunteers who had experienced mental disorders. In general there were variations in demographics that occur.

Motivation to volunteer could be grouped according to two big themes. Motivation because of their own goodness and serve others. Motivation of own goodness was divided into personal growth, altruism and self-existence. Motivation to serve others was to help others and contribute to society. The results showed that there were indeed similarities from each writer regarding motivation. The two themes that taken were a combination of several themes from each article. Determining sub-themes and topics were seen by the author by grouping them from articles. Thus, two major themes related to volunteer motivation were the own goodness and serve for others. This proved that the level of concern for others for others was still high.

The motivation of volunteers become the initial driver of the decision to get involved in a program. In this review there were several motivational studies in the program. Comper, Briending, One to one and family programs (Mccorkle et al., 2009; Cassidy et al., 2019; Klug et al., 2018; Jensen et al., 2016). The motivational aspect in the context of volunteerism looked at the reasons why people involved in volunteerism and what up holded their commitment. Overall, motivation to volunteer was a combination of altruistic interests and self-interest (Holzer, 2005). The reality was that motivation to volunteer often tended to combine elements of self-interest and altruism (Farrell \& Bryant, 2009). There were two different categories of motivation: self-oriented motivation such as learning, self-improvement and self-protection; and other oriented motivations such as building social relationships, altruistic values (Konrath et al., 2012). So basically the motivation to be a volunteer was for themselves and others. 
Motivation of own goodness and serve others was seen in several theoretical frameworks used to explain why people become a volunteer. There were three theories namely role theory, social integration theory and activity theory. Role theory, people voluntarily defend roles as productive individuals in society. Social integration theory, people volunteer because various social roles provide meaning and purpose in life, promote social support and interaction and hence contribute to feelings of well-being (Casiday et al., 2008). Activity theory, assumes that activities provide a sense of purpose and control, higher personal energy, and an active attitude in society (Ayalon, 2008). This supports that goodness for oneself was included in role theory and was devoted to others included in social integration theory and activity theory.

These findings could be a reference that volunteers had good motivation in mental health services. Volunteers who work in mental health services were people who dare to oppose opposing social views. Many studies had shown the existence of stigma and discriminatory attitudes towards people with mental disorders. The findings in this review had implications about people's attitudes towards people with mental disorders. Although in this review it was not specifically related to the benefits of community presence, but the presence of volunteers provided benefits to people with mental disorders. Volunteers were a resource that could be used as part of mental health services. Volunteers were a relatively inexpensive and easily accessible resource. Volunteers could be a part of integrated service, a health or informal partner that was useful in mental health services.

\section{CONCLUSION}

Volunteers who work in mental health services were people who dare to oppose opposing social views. Many studies had shown the existence of stigma and discriminatory attitudes towards people with mental disorders. The findings in this review had implications about people's attitudes towards people with mental disorders. Although in this review it was not specifically related to the benefits of community presence, but the presence of volunteers provided benefits to people with mental disorders. Volunteers were a resource that could be used as part of mental health services. Volunteers were a relatively inexpensive and easily accessible resource. Volunteers could be a part of integrated service, a health or informal partner that was useful in mental health services.

\section{REFERENCES}

1. AlAteeq, D., AlDaoud, A., AlHadi, A., AlKhalaf, H., \& Milev, R. (2018). The experience and impact of stigma in Saudi people with a mood disorder. Annals of general psychiatry, 17(1), 51. 
2. Angermeyer, M. C., \& Dietrich, S. (2006). Public beliefs about and attitudes towards people with mental illness: a review of population studies. Acta Psychiatrica Scandinavica, 113(3), 163-179.

3. Ayalon, L. (2008). Volunteering as a predictor of all-cause mortality: what aspects of volunteering really matter?. International Psychogeriatrics, 20(5), 1000-1013

4. Ayano, G. (2017). Significance of mental health legislation for successful primary care for mental health and community mental health services: A review. African Journal of Primary Health Care E Family Medicine, 10(1).

5. Casiday, R., Kinsman E., Fisher, C \& Bambra, C. (2008). Volunteering and Health: What impact does it really have? Report to Volunteering England. London: Volunteering England.

6. Cassidy, M., Thompson, R., El-Nagib, R., Hickling, M.L \& Priebe, S. (2019). Motivations and experiences of volunteers and patients in mental health befriending: a thematic analysis. BMC Psychiatry, 19, 116. doi: 10.1186/s12888-0192102-y

7. Pérez-Corrales, J., Pérez-de-Heredia-Torres, M., Martínez-Piedrola, R., SánchezCamarero, C., Parás-Bravo, P., \& Palacios-Ceña, D. (2019). ‘Being normal'and selfidentity: the experience of volunteering in individuals with severe mental disorders - a qualitative study. BMJ open, 9(3), e025363.

8. Farrell, C \& Bryant, W. (2009). Voluntary work for adults with mental health problems: a route to inclusion? A review of the literature. British Journal of Occupational Therapy, 72(4), 163-173.

9. Fegan, CE Cook, S. (2012). Experiences of volunteering: A partnership between service users and a mental health service in the UK. IOS PRESS, 43, 13-21. doi :10.3233/WOR 2012-1443

10. Hallett, C., Klug, G., Lauber, C \& Priebe, S. (2012). Volunteering in the care of people with severe mental illness: a systematic review. BMC Psychiatry, 12, 226.

11. Holzer, C. (2005). Ehrenamtliches Engagement: Motive pro und contra gemeinwohlorientierter freiwilliger EinsatzMaster's Thesis. University of Vienna

12. Jensen, G.L., Lou, S., Aagaard, J \& Vaeggemose, U. (2016). Community families: A qualitative study of families who volunteer to support persons with severe mental illness. International Journal of Social Psychiatry, 63(1), 33-39. doi: $10.1177 / 0020764016674346$

13. Klug, G., Toner, S., Fabisch, K \& Priebe, S. (2018). Characteristics and motivations of volunteers providing one-to-one support for people with mental illness: a survey in Austria. Social Psychiatry and Psychiatric Epidemiology, 53, 841-847.

14. Konrath, S., Fuhrel-Forbis, A., Lou, A., \& Brown, S. (2012). Motives for volunteering are associated with mortality risk in older adults. Health Psychology, 31(1), 87-96.

15. Li, J., Fan, Y., Zhongg, H. Q., Ling Duan, X., Chen, W., Lacko-Evans, S., \& Thornicroft, G. (2019). Effectiveness of an anti-stigma training on improving attitudes and 
decreasing discrimination towards people with mental disorders among care assistant workers in Guangzhou, China. International Journal of Mental Health Systems, 13(1).

16. Livingstone, J \& Boyd J. (2010). Correlates and consequences of internalized stigma for people living with mental illness: a systematic review and meta-analysis. Soc Sci Med, 71(12), 2150-61.

17. Mccorkle, H. B., Dunn, C. E., Wan, Y. M., \& Gagne, C. (2009) Compeer friends: a qualitative study of a volunteer friendship programme for people with serious mental illness. International journal of social psychiatry, 55(4): 291-305.

18. Naylor, C., Mundle, C., Weaks, L \& Buck, D. (2013). Volunteering in health and care Securing a sustainable future. England: The Kings Fund

19. Ørtenblad, L., Væggemose, U., Gissel, L., \& Nissen, N. K. (2019). Volunteering to Care for People with Severe Mental Illness: A Qualitative Study of the Significance of Professional and Private Life Experience. Community mental health journal, 55(2), 271-278.

20. Sundram, F., Corattur, T., Dong, C., \& Zhong, K. (2018). Motivations, expectations and experiences in being a mental health helplines volunteer. International journal of environmental research and public health, 15(10), 2123.

21. Toner, S., Hickling, L. M., da Costa, M. P., Cassidy, M., \& Priebe, S. (2018). Characteristics, motivations and experiences of volunteer befrienders for people with mental illness: a systematic review and narrative synthesis. BMC psychiatry, 18(1), 378.

22. WHO. (2018). Retrived from https://www.who.int/mental_health/en 